\title{
Earthquake fault of the 26 May 2006 Yogyakarta earthquake observed by SAR interferometry
}

\author{
Takeshi Tsuji ${ }^{1}$, Katsuya Yamamoto ${ }^{1}$, Toshifumi Matsuoka ${ }^{1}$, Yasuhiro Yamada ${ }^{1}$, Kyosuke Onishi $^{1}$, \\ Alfian Bahar ${ }^{2}$, Irwan Meilano ${ }^{2}$, and Hasanuddin Z. Abidin² \\ ${ }^{1}$ Graduate School of Engineering, Kyoto University, Kyoto, Japan \\ ${ }^{2}$ Institute of Technology Bandung (ITB), Jl. Ganesha 10, Bandung 40132, Indonesia
}

(Received April 1, 2009; Revised July 12, 2009; Accepted July 15, 2009; Online published August 7, 2009)

\begin{abstract}
We analyzed synthetic aperture radar interferometry (InSAR) to reveal surface deformation associated with the 26 May 2006 Yogyakarta earthquake, for which the fault location and geometry have not been clearly determined. Our results demonstrate that surface deformation occurred $\sim 10 \mathrm{~km}$ east of the Opak River fault thought to be the source of the May 2006 event and that the probable causative fault delineated in this study is consistent with aftershock epicenters determined by a temporary seismic network. The trace of the causative fault bends at its southern termination toward the Opak River fault as if it were a splay. Our data demonstrate that another probable slip plane extends across Yogyakarta and that the heavily damaged areas covered by young volcanic deposits may have undergone subsidence during the earthquake.
\end{abstract}

Key words: May 2006 Yogyakarta earthquake, SAR interferometry, fault geometry.

\section{Introduction}

On 26 May 2006 at 22:54 UTC, the Yogyakarta earthquake occurred with a left-lateral strike-slip mechanism (see Harvard-CMT, 2006; Nakano et al., 2006; NEIC-FMT, 2006; Yagi, 2006). The U.S. Geological Survey estimated the magnitude of the earthquake as $M_{\mathrm{w}} 6.3$ (USGS Preliminary Earthquake Report, 2006). Subsequently, 750 aftershocks have been reported, with the largest one measured at $M_{\mathrm{w}}$ 5.2. About 6000 people were killed, 50,000 were injured, and as many as 600,000 people were displaced in the Bantul-Yogyakarta area. More than 127,000 houses were destroyed, and an additional 451,000 were damaged in the area, with the total loss estimated at approximately 3.1 billion U.S. dollars (see Consultative Group on Indonesia, 2006). All these factors suggest that the near-surface fault systems in this tectonic setting must be characterized in order to mitigate future earthquake disasters.

The damaged area is a densely populated area along a previously mapped fault that runs northeast from the Parang Tritis area to the Bantul area and continues northward to the Klaten region (Abidin et al., 2009; Fig. 1). We refer to this mapped fault running parallel to the Opak River as the Opak River fault (Walter et al., 2008). The presence of the major southwest-northeast trending Opak River fault is thought to limit the area of tectonic subsidence of the Yogyakarta graben (Rahardjo et al., 1977). As a result, it was believed that the 2006 Yogyakarta earthquake occurred on the Opak River fault. However, the USGS estimated the hypocenter at east of the Opak River fault (USGS Preliminary Earthquake Report, 2006). The Harvard Centroid Moment Ten-

Copy right(c) The Society of Geomagnetism and Earth, Planetary and Space Sciences (SGEPSS); The Seismological Society of Japan; The Volcanological Society of Japan; The Geodetic Society of Japan; The Japanese Society for Planetary Sciences; TERRAPUB sor (CMT) solution (Harvard-CMT, 2006) suggests a significant strike-slip rupture to the east of the disaster area, and the NEIC Fast Moment Tensor (FMT) solution shows the earthquake to be on the southern section of the Opak River fault $\sim 25 \mathrm{~km}$ south of Yogyakarta (NEIC-FMT, 2006), as shown in Figs. 1 and 2(c). Nakano et al. (2006) estimated that the source was located approximately $10 \mathrm{~km}$ southsoutheast of Yogyakarta City at a depth of $10 \mathrm{~km}$ (NIED in Figs. 1 and 2(c)). Because of a scarcity of seismic stations in this area, the focal spheres estimated by several groups are widely distributed. The aftershocks determined by a temporary network of seismic stations outline an area $20 \mathrm{~km}$ long with a $50^{\circ} \mathrm{E}$ strike east of the Opak River fault (Walter et al., 2007, 2008), as shown in Fig. 2(c). Therefore, the fault location and its geometry have not been clearly determined.

This paper describes surface deformation associated with the 2006 Yogyakarta earthquake detected using interferometric SAR (InSAR) analysis and discusses an inferred fault associated with the earthquake rupture. This study may be the first application of InSAR to seismogenic fault identification of the 2006 Yogyakarta earthquake, although Matsuoka and Yamazaki (2006) applied a damage detection technique based on time-series imagery to the SAR data set of the 2006 earthquake.

\section{Geologic Setting}

Along the Java trench, the Australian plate is subducting beneath the Java continental crust (Sunda plate) with a convergence rate of $6.7 \pm 0.7 \mathrm{~cm} /$ year in a direction approximately orthogonal to the trench toward Java (Tregoning et al., 1994; Kato et al., 2007). The Australian plate dips north-northeastward from the Java trench, and the depth of the plate interface is $100-200 \mathrm{~km}$ beneath the island of Java 

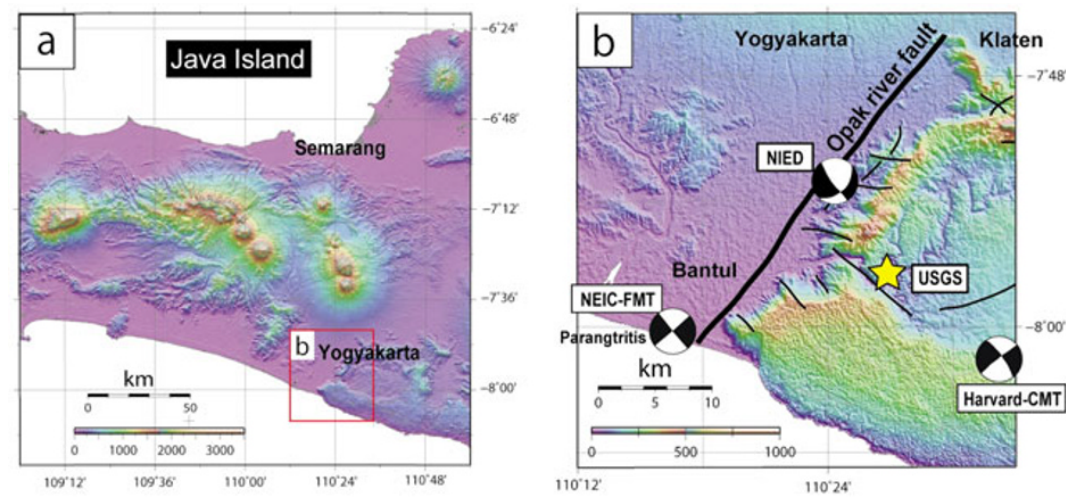

Fig. 1. (a) Digital elevation map of central Java. The red box is the area shown in Fig. 1(b). (b) Detailed map around Yogyakarta, with the epicenter of the 2006 Yogyakarta earthquake (yellow star) (USGS Preliminary Earthquake Report, 2006), estimated focal mechanisms: Harvard-CMT (2006), NEIC-FMT (2006), and NIED (Nakano et al., 2006). Black lines represent previously identified faults (Rahardjo et al., 1977; Walter et al., 2008). The thick black line is the Opak River fault. The damaged area is a densely populated area along the Opak River fault that runs roughly northeast from the Parangtritis area to the Bantul area then continues northward to the Klaten region.

(e.g., Wagner et al., 2007). The May 2006 earthquake occurred at a shallow depth in the overriding Sunda plate, well above the Australian plate; thus, the earthquake was not directly associated with the subduction regime, but rather occurred on shallower faults that were stressed by the deeper subduction mechanism. Wagner et al. (2007) interpreted the 2006 earthquake to have occurred at the edge of the weakened (fractured) area between two forearc blocks. They further argued that a change in subducting plate interface angle $150 \mathrm{~km}$ landward from the trench causes a northward pushing and stress accumulation in the overriding plate where the 2006 earthquake occurred. Therefore, this geological setting should be seismogenically active.

Our study focused on the surface deformation around the Opak River fault (Fig. 1(b)). The fault bounds a region covered by young volcanic deposits (Rahardjo et al., 1977; Lavigne and Thouret, 2002). The deposited clastic material is generally soft, consisting of breccias and pyroclastic deposits reaching a thickness of 150-200 m (Rahardjo et al., 1977). Walter et al. (2008) argued that the young volcanic deposits filled the graben bounded by the Opak River fault and amplified the ground motion to cause the disastrous damage along the Opak River fault in the 2006 event.

\section{InSAR Analysis}

InSAR has become a powerful tool to reveal synoptic deformation of the Earth's surface. Because the hypocenter of the 2006 Yogyakarta earthquake is relatively shallow (USGS Preliminary Earthquake Report, 2006), wellcharacterized surface deformation could be expected from the InSAR analysis. We compared SAR data sets acquired before the earthquake (29 April 2006) and after the earthquake (14 June 2006). The SAR data were acquired by the Phased Array Type L-band Synthetic Aperture Radar (PALSAR) instrument on the Japanese Advanced Land Observing Satellite (ALOS) "Daichi" launched in 2006. Two- or three-dimensional displacement can be estimated by combining measurements from several InSAR observation orbits. However, as we had only one pre-earthquake SAR data for the study area, we measured displacement only along the radar line-of-sight (LOS) direction (arrow
Table 1. Interferograms processed in this study.

\begin{tabular}{ll}
\hline Sensor & PALSAR \\
Orbit & Descending \\
Period & $29 / 4 / 2006-14 / 6 / 2006$ \\
Incidence angle & 38.76 \\
Cross-track angle & N77W \\
\hline
\end{tabular}

in Fig. 2; Table 1).

Data processing was performed using GAMMA software. To eliminate the effect of the difference in the satellite positions for the two acquisitions of a pair, we used $~ 90-\mathrm{m}$ mesh digital elevation models (Shuttle Radar Topography Mission; SRTM-3). We further applied an adaptive filter (Goldstein and Werner, 1998; Li et al., 2006) for the SAR interferograms (Fig. 2(a)) because the interferograms contained high-frequency noise that obscured large-scale deformation associated with the earthquake. This filtering process significantly improved our results (Fig. 2(b-e)).

The ground surface displacement inferred via InSAR (Fig. 2) demonstrated that deformation occurred at $\sim 10 \mathrm{~km}$ east of the Opak River fault. The estimated surface trace of this earthquake rupture fault (red line in Fig. 2(d); red arrows in Fig. 2(e)) is parallel to the Opak River fault (thick black line in Fig. 2(d); black arrows in Fig. 2(e)) and directly above the hypocenter reported by USGS (USGS Preliminary Earthquake Report, 2006). Although the deformation was near the edge of the analyzed area, the displacement was clearly apparent. Because this fault trace is not related to the topographic boundary associated with the Opak River fault (Fig. 2(e)), the estimated displacement was not affected by surface geometry. The absence of clear surface deformation along the Opak River fault (Fig. 2(e)) led us to conclude that it did not experience coseismic slip in this event.

We identified a linear surface deformation across Yogyakarta (orange line in Fig. 2(d); orange arrow in Fig. 2(e)), striking parallel to the earthquake rupture fault. The ground surface to its east was moving away from the satellite and, therefore, the damage area covered by young volcanic deposits (Walter et al., 2008) appears to be an area 

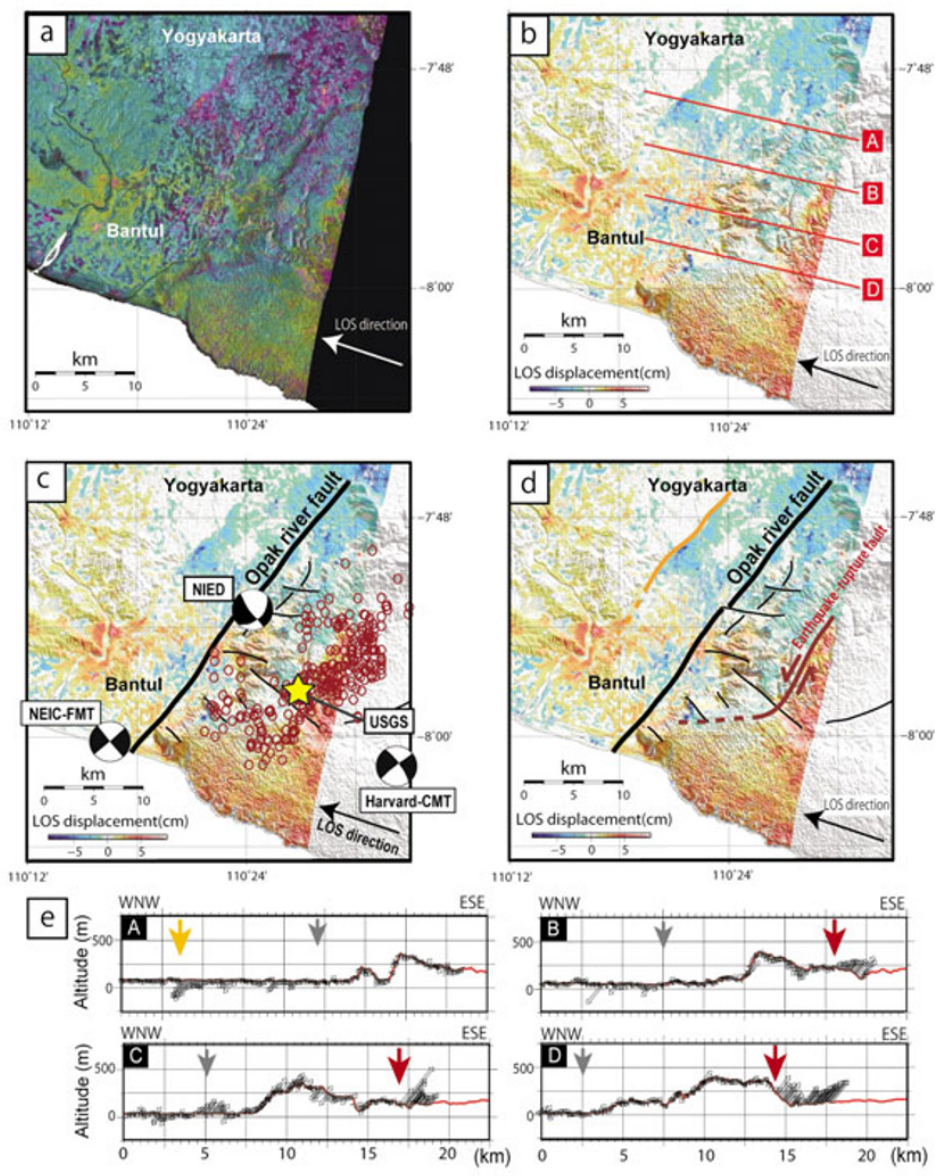

Fig. 2. (a) Differential interferograms computed from PALSAR data. The analyzed area corresponds to Fig. 1(b). The colors represent the phase difference between SAR data pairs. Arrow represents LOS direction. (b) Inferred ground surface deformation. The warmer color represents displacement toward the satellite. (c) Ground surface deformation, epicenter of the 2006 Yogyakarta earthquake (yellow star) (USGS Preliminary Earthquake Report, 2006), estimated focal mechanisms (Harvard-CMT, 2006; Nakano et al., 2006; NEIC-FMT, 2006), and aftershock epicenters (red circles) (Walter et al., 2008). Faults are depicted as in Fig. 1. (d) Inferred trace of earthquake rupture fault from ground surface deformation (red line). Orange line across Yogyakarta represents the western edge of the subsidence area. (e) Deformation profiles across the rupture fault. The location of each profile (A-D) corresponds to red lines in Fig. 2(b). White arrows represent surface deformations for LOS direction. Red and gray arrows represent the ruptured fault in 2006 event and Opak River fault, respectively.

of subsidence.

\section{Discussion}

Based on the aftershock distribution determined by the temporary dense seismometer network of the German Task Force, Walter et al. (2007) demonstrated that the Yogyakarta earthquake rupture fault lies $10-20 \mathrm{~km}$ east of the disaster area, outside of the topographic depression associated with the Opak River fault. Our results are consistent with this location of the aftershock cluster (red dots in Fig. 2(c)) (Walter et al., 2007, 2008). Although the aftershock hypocenters are distributed at a depth of 8-15 km, we observed clear deformation at the ground surface. Therefore, the deformation seems to be propagating upward to the ground surface from the coseismic fault plane. Our study further reveals that the fault geometry is not straight. The fault trace appears to be bending at its southern termination as if it were a splay from the Opak River fault (Fig. 2(d)).

Using GPS observations, Abidin et al. (2009) showed that horizontal coseismic displacements around Bantul and Yogyakarta are mostly $<10 \mathrm{~cm}$, with south and southwest directions. Because the GPS observation points are mostly located on the western side of the ruptured fault trace, these displacements are consistent with our results. Abidin et al. (2009) modeled the fault geometry from the GPS-derived displacements, using the Okada model (Okada, 1985) and a genetic algorithm, as a left-lateral fault with a strike of $\mathrm{N} 48^{\circ} \mathrm{E}$ and a dip of $89^{\circ}$ located slightly to the east of the Opak River fault. This model is consistent with the surface deformation we obtained via InSAR.

At the north end of the aftershock cluster, the aftershocks distributed at a depth ranging from 8 to $15 \mathrm{~km}$ lie slightly east of the fault trace estimated via InSAR (Fig. 2(c)). Therefore, the earthquake rupture fault plane may be eastdipping (Fig. 3). The velocity model inverted from active and passive seismic data (Wagner et al., 2007) showed that an east-dipping low-velocity zone due to developed fractures occurs below this region. Furthermore, the surface deformation showed that the eastern side of the newly observed fault moved toward the satellite (warmer color in Fig. 2(b-d)). It is difficult to distinguish pure strike-slip movement because the LOS direction is almost perpendicular to the fault trace. Therefore, we infer that the coseismic displacement had a component of reverse slip in addition to 


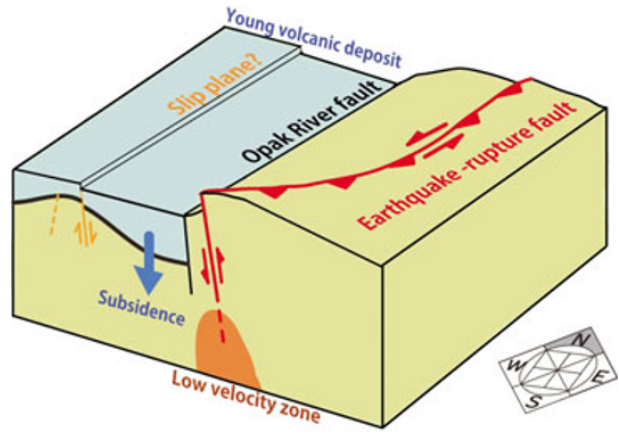

Fig. 3. Schematic diagram of the relation between the earthquake rupture fault (red line), the Opak River fault (black line), and subsidence in young volcanic deposits. The displacement across Yogyakarta may reflect normal fault displacement on a slip plane associated with a forebulge. The orange zone represents the low-velocity region (Wagner et al., 2007).

the strike-slip along the steep fault plane and that the eastern side of the fault experienced up-dip displacement (Fig. 2(e), Fig. 3).

The linear zone of deformation across Yogyakarta on the InSAR map (orange line in Fig. 2(d)) appears to bound a zone of subsidence in the young volcanic deposits west of the Opak River fault that corresponds to areas of strong ground motion (Walter et al., 2008). Therefore, there is a possibility that strong ground motion induced the subsidence of the volcanic deposits (Lavigne and Thouret, 2002). Furthermore, if the earthquake rupture fault indeed has a reverse component, it may be that the subsurface displacement in Yogyakarta occurred at a normal fault associated with the forebulge to that fault, shown schematically in Fig. 3, given that the linear deformation across Yogyakarta is parallel to the earthquake rupture fault.

\section{Summary}

(1) The deformation map estimated by InSAR indicates that surface deformation occurred $\sim 10 \mathrm{~km}$ east of the Opak River fault, which was previously thought to be the seismogenic fault for the 2006 Yogyakarta earthquake. We were unable to identify clear deformation along the Opak River fault.

(2) Our SAR study showed that the earthquake rupture fault trace was parallel to the Opak River fault, bending toward it at its southern termination.

(3) The fault trace of our inferred seismogenic fault is consistent with aftershock epicenters determined by temporary dense seismometer network.

(4) The earthquake displacement had a component of reverse slip in addition to the strike-slip along the eastdipping fault plane.

(5) A linear deformation zone across Yogyakarta was identified on the InSAR deformation map. The young volcanic deposits along the Opak River fault seem to have undergone subsidence that may have resulted from strong ground motion. We further speculate that the existence of this subsurface displacement plane may be due to normal faulting at the forebulge of the seismogenic fault.

Acknowledgments. This research was supported by GCOE "Global Center for Education and Research on Human Secu- rity Engineering for Asian Megacities" and Earth Remote Sensing Data Analysis Center (ERSDAC). We thank H. Permana (Indonesian Institute of Sciences) for valuable discussions. Y. Fukushima (Kyoto University) gave us useful advice in InSAR analysis. We also thank Y. Ito (Tohoku University) and T. Walter (GeoForschungsZentrum Potsdam) for reviews of the manuscript and helpful comments. T. Walter further provided the aftershock data from the German Task Force temporary array.

\section{References}

Abidin, H. Z., H. Andreas, T. Kato, T. Ito, I. Meilano, F. Kimata, D. H. Natawidjaya, and H. Harjono, Crustal deformation studies in Java (Indonesia) using GPS, J. Earthq. Tsunami, 3, 77-88, 2009.

Consultative Group on Indonesia, Preliminary damage and loss assessment, Yogyakarta and central Java natural disaster: A joint report of BAPPENAS, the provincial and local governments of D.I. Yogyakarta, the provincial and local governments of central Java, and international partners, in The 15th Meeting of the Consultative Group on Indonesia (CGI) Jakarta, June 14, 2006, 140 pp., Jakarta, 2006

Goldstein, R. M. and C. L. Werner, Radar interferogram filtering for geophysical applications, Geophys. Res. Lett., 25, 4035-4038, 1998.

Harvard-CMT, Focal mechanism of the 2006 Yogyakarta earthquake, The website of the Harvard Global CMT, id\#20062253A, (available at http://www.globalcmt.org), 2006.

Kato, T., T. Ito, H. Z. Abidin, and Agustan, Preliminary report on crustal deformation surveys and tsunami measurements caused by the July17, 2006 South off Java Island Earthquake and Tsunami, Indonesia, Earth Planets Space, 59, 1055-1059, 2007.

Lavigne, F. and J.-C. Thouret, Sediment transportation and deposition by rain-triggered lahars at Merapi Volcano, Central Java, Indonesia, Geomorphology, 49, 45-69, 2002.

Li, Z. W., X. L. Ding, C. Huang, D. W. Zheng, W. B. Zou, and Y. K. Shea, Filtering method of SAR interferograms with strong noise, Int. J. Remote Sensing, 27, 2991-3000, 2006.

Matsuoka, M. and F. Yamazaki, Use of SAR imagery for monitoring areas damaged due to the 2006 Mid Java, Indonesia earthquake, Proceedings of 4 th international workshop on remote sensing for post-disaster response, (available at http://www.arct.cam.ac.uk /curbe/4thInt_workshop.html), 2006.

Nakano, M., H. Kumagai, K. Miyakawa, T. Yamashita, H. Inoue, M. Ishida, S. Aoi, N. Morikawa, and P. Harjadi, Source Estimates of the May 2006 Java Earthquake, EOS Trans. AGU, 87, 45, doi:10.1029/2006EO450002, 2006.

NEIC-FMT, Focal mechanism of the 2006 Yogyakarta earthquake, The website of U.S. National Earthquake Information Center (NEIC), (available at http://neic.usgs.gov/neis/eq_depot/2006/eq_060526_neb6/ neic_neb6_q.html), 2006.

Okada, Y., Surface deformation due to shear and tensile faults in a halfspace, Bull. Seismol. Soc. Am., 75, 1135-1154, 1985.

Rahardjo, W., Sukandarrumidi, and H. Rosidi, Geologic map of the Yogyakarta quadrangle, Java, scale $1: 100,000,8$ pp., Geol. Surv. Indonesia, Minist. of Mines, Jakarta, 1977.

Tregoning, P., F. K. Brunner, Y. Bock, S. O. O. Puntodewo, R. McCaffery, J. F. Genrich, E. Calais, J. Rais, and C. Subarya, First geodetic measurement of convergence across the Java Trench, Geophys. Res. Lett., 21, 2135-2138, 1994.

USGS Preliminary Earthquake Report, The website of United States Geological Survey, Earthquake Hazards Program, (available at http://earthquake.usgs.gov/eqcenter/eqinthenews /2006/usneb6/), 2006.

Wagner, D., I. Koulakov, W. Rabbel, B.-G. Luehr, A. Wittwer, H. Kopp, M. Bohm, and G. Asch, Joint inversion of active and passive seismic data in central Java, Geophys. J. Int., 170(2), 923-932, doi:10.1111/j.1365246X. 2007.03435.x, 2007.

Walter, T. R., B. Luhr, M. Sobiesiak, H. Grosser, R. Wang, S. Parolai, H.-U. Wetzel, J. Zschau, C. Milkereit, and E. Cunther, Soft volcanic sediments compound 2006 Java Earthquake disaster, EOS, 88(46), 486, 13 November 2007, doi: 10.1029/2007EO460002, 2007.

Walter, T. R. et al., The 26 May 2006 magnitude 6.4 Yogyakarta earthquake south of Mt. Merapi volcano: Did lahar deposits amplify ground shaking and thus lead to the disaster?, Geochem. Geophys. Geosyst., 9, Q05006, doi:10.1029 /2007GC001810, 2008.

Yagi, Y., Earthquake which occurred near the Yogyakarta city on May 26, 2006, Int. Inst. Seismol. Earthquake Eng., Tsukuba, Japan, (available at http://www.geo.tsukuba.ac.jp/press_HP/yagi/EQ/ 2006Jawa/), 2006.

T. Tsuji (e-mail: tsuji@earth.kumst.kyoto-u.ac.jp), K. Yamamoto, T. Matsuoka, Y. Yamada, K. Onishi, A. Bahar, I. Meilano, and H. Z. Abidin 